\title{
Reuse of lead glass sludge in the fabrication of thermally insulating foamed glass with outstanding properties and high $\mathrm{Pb}$-stabilization
}

\author{
Hamdy A. Abdel-Gawwad ${ }^{1} \cdot$ Mona S. Mohammed $^{2} \cdot$ Mohammed A. Arif $^{3} \cdot$ Hamada Shoukry $^{4}$
}

Received: 4 November 2021 / Accepted: 8 February 2022 / Published online: 18 February 2022

(c) The Author(s) 2022

\begin{abstract}
This study represents the sustainable/safe consumption of lead glass sludge (LGS) in the fabrication of thermally insulating foamed glass via sintering $\left(750-950^{\circ} \mathrm{C}\right)$ and chlorination processes. The impact of selected additives including calcium chloride $\left(\mathrm{CaCl}_{2}\right)$ and sodium hydroxide $(\mathrm{NaOH})$ on the foaming efficiency and $\mathrm{Pb}$-stabilization has been deeply investigated. LGS is mainly lead silicate material with considerable content of calcium carbonate, which acts as foaming agent during sintering process. The newly developed foamed-materials exhibited thermal conductivity of $0.054-0.136 \mathrm{~W} / \mathrm{m} . \mathrm{K}$, density of $0.23-1.10 \mathrm{~g} / \mathrm{cm}^{3}$, porosity of $63.3-92.6 \%$, and compressive strength of 0.10-2.69 MPa. X-ray diffraction proved that the immobilization mechanism was attributed to the transformation of free $\mathrm{Pb}$ within LGS into insoluble ganomalite $\mathrm{Pb}_{9} \mathrm{Ca}_{5} \mathrm{MnSi}_{9} \mathrm{O}_{33}$ phase. Adding $\mathrm{NaOH}$ enhanced the foaming process accompanied by a significant reduction in $\mathrm{Pb}$-leaching. Incorporating $\mathrm{CaCl}_{2}$ has resulted in a retardation in $\mathrm{Pb}$-leaching, which associated with $\mathrm{Pb}$-stabilization and $\mathrm{Pb}$-vaporization. In an attempt to reduce $\mathrm{CO}_{2}$-emission, the potential use of alkali-rich-wastewater (AW) as eco-friendly alkali source in lieu of $\mathrm{NaOH}$ was studied. Regardless of the variation in $\mathrm{Pb}$-concentrations in leachates, all samples recorded $\mathrm{Pb}$-concentrations lower than the safe limit $(\leq 5 \mathrm{mg} / \mathrm{l})$, achieving Pb-immobilization of $95.98-99.87 \%$. The significantly reduced thermal conductivity and enhanced $\mathrm{Pb}$-immobilization efficiency along with the reasonable compressive strength summarize the major innovation presented in this study.
\end{abstract}

Keywords Foamed glass $\cdot$ Sintering $\cdot$ Leaching; Porosity $\cdot$ Thermal conductivity $\cdot$ Compressive strength

\section{Introduction}

Lead $(\mathrm{Pb})$-bearing-wastes are categorized as accumulative hazardous pollutants, which cause serious problems to the human health and environment (WHO, 2019). The united

Responsible Editor: Santiago V. Luis

Hamdy A. Abdel-Gawwad hamdyabdelgawwad@yahoo.com;

hamdy.abdelgawwad@hbrc.edu.eg

1 Raw Building Materials and Processing Technology Research Institute, Housing and Building National Research Center (HBRC), Cairo, Egypt

2 Department of Chemical Engineering and Pilot Plant, National Research Centre, Cairo, Egypt

3 Department of Chemistry, Faculty of Science, Zagazig University, Zagazig, Egypt

$4 \quad$ Building Physics Institute (BPI), Building National Research Center (HBRC), Housing \&, Cairo, Egypt nation environment program showed that there is no safe limit for exposure to $\mathrm{Pb}$, as the lowest dose causes problems in the human nervous system (UNEP 2013). Stabilization/ solidification of $\mathrm{Pb}$-contaminated-wastes is mandatory to overcome the hazardous effect of this metal. Accordingly, different research approaches were implemented to transform the hazardous lead into safe and inactive materials. The immobilization of $\mathrm{Pb}$ using Portland cement (Wang et al. 2018; Niu et al. 2018), alkali-activated cement (Eleswed 2020; Li et al. 2021), and reactive magnesia (Shen et al. 2018, 2019a, b; Abdel-Gawwad et al. 2021) has been extensively addressed. Physical immobilization of $\mathrm{Pb}$ within calcium silicate hydrate phase (Wang et al. 2018), the incorporation of $\mathrm{Pb}$ within aluminosilicate network (El-eswed et al. 2017), and the formation of $\mathrm{Pb}$ hydroxide, cerussite, and hydrocerussite (Zhan et al. 2020) are the main suggested mechanism of Pb-stabilization via Portland cement, alkaliactivated cement, and reactive magnesia, respectively.

Thermal treatment of Pb-bearing-wastes is one of the most effective methods for stabilization and removal of 
$\mathrm{Pb}$. Adding chloride salt before thermal treatment greatly enhanced the removal of $\mathrm{Pb}$ via chlorination/evaporation process (Yu et al. 2013; Nowak et al. 2010; Nowak et al. 2012). Chloride can chlorinate $\mathrm{PbO}$ at $800-900{ }^{\circ} \mathrm{C}$ to yield $\mathrm{PbCl}_{2}$ with lower melting point compared with $\mathrm{PbO}$, resulting in an enhancement in $\mathrm{Pb}$ volatilization. The presence of mineral matter ( $\mathrm{Si}$ and $\mathrm{Al}$ ) can hinder $\mathrm{Pb}$-evaporation, which associated with the formation nonvolatile $\mathrm{Pb}$-metallic species (Yu et al. 2013). Magnesium chloride, calcium chloride, and sodium chloride salts are the main chloride salts used in the chlorination of $\mathrm{Pb}$ (Nowak et al. 2012). Poly vinyl chloride (PVC) was previously used as organic chloride source. Nowak et al. 2010, 2012) found that the chlorination/evaporation of $\mathrm{Pb}$ via calcium chloride is more efficient than sodium chloride. Calcium oxide was found to exhibit a retardation effect on PVC-induced $\mathrm{Pb}$-volatilization; whereas it has no effect on the direct chlorination of sodium chloride-containing-system (Wang et al. 2017).

The environmental pollution resulted from glass manufacturing can be partitioned into three types: solid waste, waste water, and air emission (FC 2007). Regarding lead glass industry lead component was used as the main ingredient in this manufacturing. Almost $30 \%$ of lead used escapes during manufacturing stages including transportation and batch preparation, melting process in the furnace, and grinding and polishing (Pechnikov et al. 1996). Lead glass sludge (LGS) is categorized as a hazardous waste resulted during the grinding and polishing of lead glass. Lead glass industry annually produces 6.3 million tonnes all over the world (Bursi et al. 2017). Approximately 20 tonnes/day was resulted from lead glass manufacturing in Egypt (Elkersh 2014). LGS has been transformed into safe building material via its incorporation in alkali-activated slag (Abdel-Gawwad et al. 2019; 2020a) and magnesia-based bricks (Abdel-Gawwad et al. 2021).

Apart from the thermal treatment/chlorination of $\mathrm{Pb}$-containing-wastes demonstrate high efficiency in Pb-removal, the rest ash from incineration of solid wastes contributes to environmental problems including falling landfill space and landfill contamination. Accordingly, the application of thermal treatment and chlorination for the remediation of $\mathrm{Pb}$ bearing-materials through the production of a widely used and a safe product is the main challenge. Therefore, the novel contribution of the present work is to utilize chlorination and thermal treatment for immobilization/removal of $\mathrm{Pb}$ containing-glass sludge through the fabrication of thermally insulating glass foam with high stability to acidic media. The impact of calcium chloride (chlorination) and sodium hydroxide addition on the foaming process and $\mathrm{Pb}$-remediation within sintered-LGS. Owing to the manufacture of sodium hydroxide generates high $\mathrm{CO}_{2}$ emission (Turner and Collins 2013; McLellan et al. 2011), alkali-rich-wastewater
(AW) from aluminum pots manufacturing was used as ecofriendly alkali source. The mechanism of $\mathrm{Pb}$-stabilization through thermochemical treatment of LGS has been also addressed.

\section{Experimental}

\section{Materials}

As the main starting material of foamed-glass, LGS (which was resulted from polishing of glass crystal) was supplied from ASFOUR Company for Glass Crystals Industry (Cairo, Egypt). Ultra-pure sodium hydroxide $(\mathrm{NaOH})$ and calcium chloride $\left(\mathrm{CaCl}_{2}\right)$, as additives for LGS, were purchased from Fisher Scientific Chemical Company (UK). AW from aluminum pots manufacturing, was used as an alternative to chemical $\mathrm{NaOH}$. AW exhibits $\mathrm{Na}^{+}$content of $64,345 \mathrm{mg} / 1$ and $\mathrm{pH}$ of $13.15 \pm 0.2$.

\section{Preparation of foamed-LGS}

The formation of foamed-LGS includes three main stages, i.e., LGS-grinding (grinding was conducted in a ball mill to achieve fineness of $6200 \mathrm{~cm}^{2} / \mathrm{g}$ ), wet mixing and molding, and sintering at elevated temperatures. Simply, the LGS powder was mixed with water at water to LGS weight ratio of 0.40 . The workable paste was transferred into stainless steel mold of $50 \times 125 \times 25 \mathrm{~mm}$ (width $\times$ length $\times$ height, respectively), followed by sintering at different elevated temperatures. Owing to high-volume change occurs after sintering process, the workable LGS-paste should spread along the surface's mold to yield a layer with an average height of $3 \mathrm{~mm}$ to avoid get off the foamed-LGS sample from the mold after sintering. The foamed materials left to cool in an oven for $24 \mathrm{~h}$, then carefully demolded. As shown in Table 1, thirteen mixtures have been prepared in the present work. Four mixtures were prepared by the exposure of LGS mixed with tap water (TW) to 750,800 , 850 , and $950^{\circ} \mathrm{C}$ for holding time (sintering time) of $2 \mathrm{~h}$. At constant mixing water (TW) and sintering temperature (850 $\left.{ }^{\circ} \mathrm{C}\right)$, two mixtures have been prepared at different holding times of 1 and $3 \mathrm{~h}$. Other three mixtures, in which LGS was individually mixed 1,3 , and $5 \mathrm{wt} . \% \mathrm{NaOH}$, were synthesized at sintering temperature of $850{ }^{\circ} \mathrm{C}$ and holding time of $2 \mathrm{~h} . \mathrm{CaCl}_{2}$ solutions with concentrations of 1,3 , and $5 \mathrm{wt} . \%$ were mixed with LGS, then exposed to the same sintering conditions to yield three foamed-LGS samples. The last foamed sample was synthesized by sintering LGS mixed $\mathrm{CaCl}_{2}$ solution with concentration of $3 \mathrm{wt} . \%$ using $\mathrm{AW}$ as a solvent. Three samples of each mixtures were prepared and 
Table 1 Details of mixing proportions and sintering conditions of foamed LGS

\begin{tabular}{lllllll}
\hline Mix notation & $\begin{array}{l}\text { LGS } \\
\text { Wt.\% }\end{array}$ & NaOH & $\mathrm{CaCl}_{2}$ & $\begin{array}{l}\text { Temperature } \\
{ }^{\circ} \mathrm{C}\end{array}$ & $\begin{array}{l}\text { Holding time } \\
\text { hour }\end{array}$ & $\begin{array}{l}\text { Type of } \\
\text { mixing } \\
\text { water }\end{array}$ \\
\hline F-LGS-750 (2 h) & 100 & - & - & 750 & 2 & TW \\
F-LGS-800 (2 h) & 100 & - & - & 800 & 2 & TW \\
F-LGS-850 (1 h) & 100 & - & - & 850 & 1 & TW \\
F-LGS-850 (2 h) & 100 & - & - & 850 & 2 & TW \\
F-LGS-850 (3 h) & 100 & - & - & 850 & 3 & TW \\
F-LGS-950 (2 h) & 100 & - & - & 950 & 2 & TW \\
F-LGS-850 (2 h)-SH1 & 100 & 1 & - & 850 & 2 & TW \\
F-LGS-850 (2 h)-SH3 & 100 & 3 & - & 850 & 2 & TW \\
F-LGS-850 (2 h)-SH5 & 100 & 5 & - & 850 & 2 & TW \\
F-LGS-850 (2 h)-CC1 & 100 & - & 1 & 850 & 2 & TW \\
F-LGS-850 (2 h)-CC3 & 100 & - & 3 & 850 & 2 & TW \\
F-LGS-850 (2 h)-CC5 & 100 & - & 5 & 850 & 2 & TW \\
F-LGS-850 (2 h)-CC3 / AW & 100 & - & 3 & 850 & 2 & AW \\
\hline
\end{tabular}

characterized using different experimental methods (which were discussed below).

\section{Methods}

The effectiveness of foaming process at different conditions was evaluated by conducting different experimental methods on the produced foamed materials. Volume expansion $\%$ ( $\mathrm{V}_{\text {exp }}$ : after sintering process) was determined according to the following equation:

$\operatorname{Vexp}(\%)=\frac{V i-V s}{\mathrm{Vi}} \times 100$

$V i$ and $V s$ are the initial and final volumes after sintering process, respectively.

The bulk density $\left(\mathrm{g} / \mathrm{cm}^{3}\right)$ was simply carried out according to ASTM C303 (2021) by dividing dry mass to volume ratio of the sintered sample. He-pycnometer (Micromeritics AccuPyc 1330, Norcross, GA) was used to determine the amounts of total, open, and closed porosity. Before measuring compressive strength, the foamed materials were cut into $50 \times 50 \times 50 \mathrm{~mm}$ (width $\times$ length $\times$ height, respectively). Followed ASTM C109M (2020), compressive strength was conducted on three samples of each mixture. This test was operated by means of five tons of German-Bruf-Pressing Machine with a maximum capacity of $175 \mathrm{kN}$.

The leaching of $\mathrm{Pb}$ from LGS before and after sintering process was measured by acetic acid leaching test. According to toxicity characteristic leaching procedures (TCLP: USEPA 1992), $5 \mathrm{~g}$ of sample was suspended in $100 \mathrm{ml}$ of $0.1 \mathrm{M}$ acetic acid solution with $\mathrm{pH}$ of $2.9 \pm 0.05$. Thereafter, shaking was applied on the acetic acid solution containing sample for $18 \mathrm{~h}$, followed by filtration using Whitman filter paper (Grade 41). The total bioavailable $\mathrm{Pb}$ within LGS was determined by mixing $0.25 \mathrm{~g}$ of a powdered-sample with $9 \mathrm{~mL}$ of $\mathrm{HNO}_{3}$ with a concentration of $70 \mathrm{wt} . \%$ and $3 \mathrm{~mL}$ of $\mathrm{HCl}$ with a concentration of $36 \mathrm{wt}$. \%. The sequential $\mathrm{Pb}$ leaching test is categorized as an important method to determine the behavior of Pb-leaching (Shen et al. 2018, 2019a, b). The $\mathrm{Pb}$ leaching was divided into four fractions including exchangeable, acid soluble, organic bound, and nonbioavailable $\mathrm{Pb}$-fractions. Exchangeable $\mathrm{Pb}$-fraction was determined by mixing $1 \mathrm{~g}$ of sintered and un-sintered LGS with $8 \mathrm{~mL}$ of $\mathrm{MgCl}_{2}$ solution $(0.5 \mathrm{M})$ at $\mathrm{pH}$ of 7 ( $\mathrm{NaOH}$ was used to adjust $\mathrm{pH}$ ). The suspended solution was shaken at $250 \mathrm{rpm}$ and a temperature of $23 \pm 2{ }^{\circ} \mathrm{C}$ for $20 \mathrm{~min}$, followed by filtration. Before conducting acidic soluble $\mathrm{Pb}$-fraction, the solid residue from the exchangeable $\mathrm{Pb}$-fraction step was washed many times by distilled water to remove any contaminants. The acidic soluble fraction test was carried out by suspending the washed solid residue from the previous test in $8 \mathrm{~mL}$ of $1 \mathrm{M}$ sodium acetate solution at $\mathrm{pH} 5(\mathrm{pH}$ was adjusted by $0.1 \mathrm{M}$ acetic acid), followed by shaking at $250 \mathrm{rpm}$ and a temperature of $23 \pm 2{ }^{\circ} \mathrm{C}$ for $5 \mathrm{~h}$. To determine the $\mathrm{Pb}$ bound to organic matter, the washed solid residue from acidic soluble $\mathrm{Pb}$-fraction test was shaken in $20 \mathrm{~mL}$ of $30 \% \mathrm{H}_{2} \mathrm{O}_{2}$ and $0.02 \mathrm{M} \mathrm{NH}_{2} \mathrm{OH}$ at $\mathrm{pH}$ of 2.0. This mixture was mixed with $20 \% \mathrm{HNO}_{3}$ and 3 mol ammonium acetate. Finally, the non-bioavailable $\mathrm{Pb}$-fraction was estimated by subtracting the total bioavailable $\mathrm{Pb}$ (7953 mg/Kg) from four $\mathrm{Pb}$-fractions.

After each $\mathrm{Pb}$-fraction, centrifuging and filtration were applied to separate leachate from the solid residue. The insoluble residue was washed by $20 \mathrm{~mL}$ of deionized water to remove any impurities on its surface, before its usage in 
the next step. The filtrate (leachate) from each $\mathrm{Pb}$-fraction was acidified and diluted prior to $\mathrm{Pb}$ measurement using inductively coupled plasma atomic emission (ICP-AE) spectroscopy instrument (ULTIMA2, Horiba, Japan). The sequential $\mathrm{Pb}$-extraction test was conducted three times, and the average was calculated and recorded.

\section{Instrumental analyses}

X-ray diffraction (XRD) was conducted to identify the phase composition of LGS and the change occurred after the sintering LGS sample at different conditions. XRD was conducted using a Philips PW3050/60 diffractometer. Sample was scanned under the following conditions: radiation source of $\mathrm{Cu} \mathrm{K \alpha}$ at $\Lambda=1.5419 \AA$; divergence slit adjusted at $10 \mathrm{~mm}$ in-plane; scanning range of 5-50 $2 \theta^{\circ}$; scanning rate of $0.5^{\circ}$ $2 \theta \mathrm{min}^{-1}$; sampling interval of $0.02^{\circ} 2 \theta$. X-ray florescence (XRF: Xios PW 1400) was used for a quantitative analysis to determine the oxides analysis of LGS. Thermogravimetric analysis (TGA) and its derivative (DTG) was applied to identify the weight loss related to different phases within LGS. Differential thermal analysis (DTA) also was used to determine the softening point of silicate within LGS. TGA and DTA was conducted using a DT-50 thermal analyzer (Schimadzu Co-Kyoto, Japan). These tests were performed by weighing $20 \mathrm{mg}$ of a powdered-LGS IN Pt-crucible, followed by heating in $\mathrm{N}_{2}$-atmosphere at $1000^{\circ} \mathrm{C}$ with a heating rate of $10^{\circ} \mathrm{C} /$ minute. The pore system of the foamed LGS was investigated by Leica S8 APO stereo-microscopy.

The transient line heat source method for measuring thermal properties of porous solid structures has been effectively adopted in many previous studies (Kim et al. 2003; Demirboga 2003; Al-Jabri et al. 2021). In the current study, KD2 Pro [Meter group, Washington] thermal properties analyzer was used to determine the thermal conductivity of the developed composites according to ASTM D5334-14. The dual needle $1.3 \mathrm{~mm}$ dia. $\times 30 \mathrm{~mm}$ long, $6 \mathrm{~mm}$ spacing was used. Two parallel grooves were created in test specimens with the aid of a 6-mm spacer; thermal grease was used to avoid the contact thermal resistance of the probe. Three specimens were tested for every mix and the average values were reported. To eliminate the influence of moisture content on values of thermal conductivity, the test specimens were dried at $100{ }^{\circ} \mathrm{C}$ for $24 \mathrm{~h}$ before testing.

\section{Results}

\section{Characterization of LGS}

XRD shows (Fig. 1) that LGS exhibits amorphous pattern with the appearance of crystalline peaks affiliated to calcium carbonate $\left(\mathrm{CaCO}_{3}\right)$ and silicon. $\mathrm{SiO}_{2}$ and $\mathrm{PbO}$
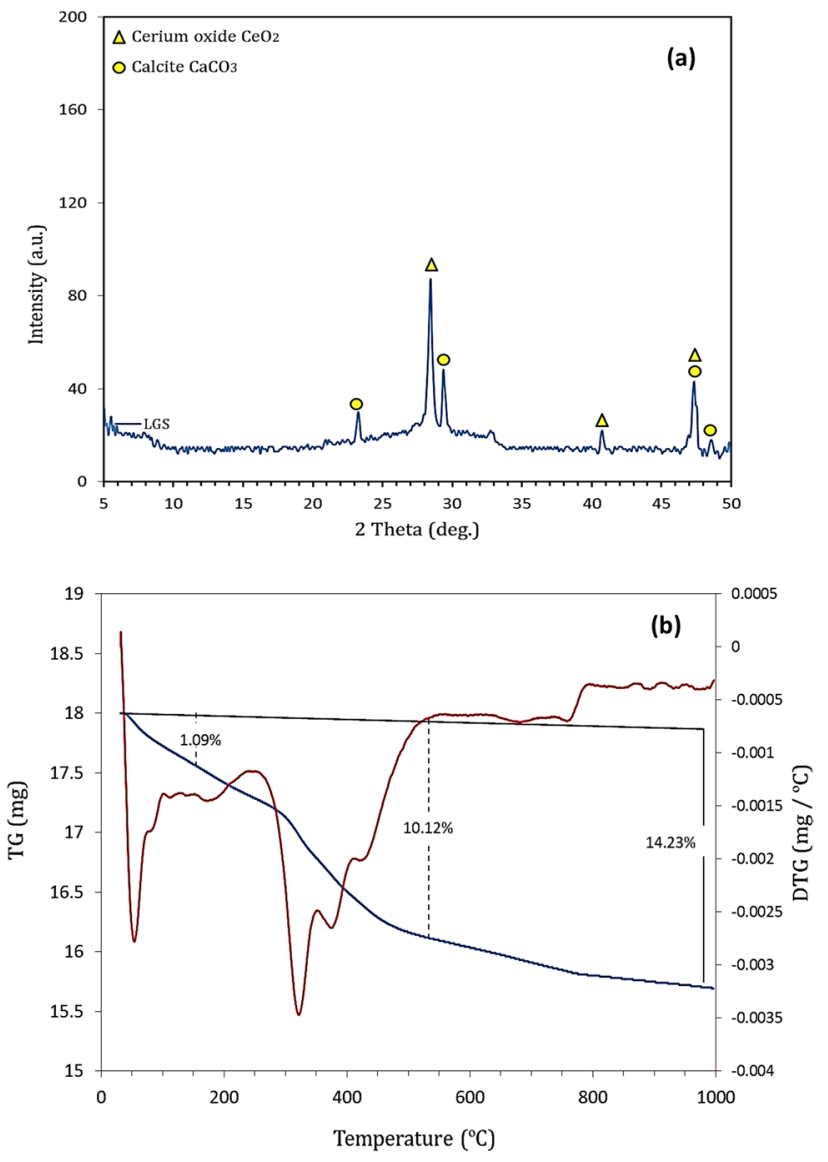

Fig. 1 XRD-pattern (a) and TG/DTG-curves (b) of LGS

represent approximately $60 \%$ of the total oxides of LGS (Table 2), suggesting that LGS is lead silicate-rich-waste. Stoichiometrically, the $\mathrm{CaCO}_{3}$ content within LGS can be estimated by means of $\mathrm{CaO}$ content, as $3.69 \% \mathrm{CaO}$ is resulted from the dissociation of $6.58 \% \mathrm{CaCO}_{3}$. TG/DTGcurve (Fig. 1) proves that there are three weight losses affiliated to dehydration of free water $\left(50-70^{\circ} \mathrm{C}\right)$, dissociation of organic matter $\left(200-550^{\circ} \mathrm{C}\right)$, and the decomposition of $\mathrm{CaCO}_{3}\left(700-850^{\circ} \mathrm{C}\right)$. This indicates that the loss on ignition listed in Table 2 is the summation of weight losses of these phases. As identified by TG-curve, the weight loss affiliated to organic matter equals $10.12 \%$, representing $71 \%$ of the total weight loss of LGS. On the other hand, the weight loss affiliated to $\mathrm{CO}_{2}(3.02 \%)$ is mainly resulted from the dissociation of $6.86 \% \mathrm{CaCO}_{3}$. This value is nearly closed to that $(6.58 \%)$ estimated from XRF-analysis (Table 2), suggesting the identified $\mathrm{CaO}$ content is mainly affiliated to $\mathrm{CaCO}_{3}$ within LGS.

\section{Characterization of LGS foams}

The sintering LGS has resulted in the formation of foamedmaterials with different pore systems depending on treatment 
Table 2 Oxides compositions of LGS

\begin{tabular}{|c|c|c|c|c|c|c|c|c|c|c|c|c|c|c|}
\hline \multirow[t]{2}{*}{ Notations } & \multicolumn{14}{|c|}{ Oxides wt. \% } \\
\hline & $\mathrm{SiO}_{2}$ & $\mathrm{CaO}$ & $\mathrm{MgO}$ & $\mathrm{Fe}_{2} \mathrm{O}_{3}$ & $\mathrm{Al}_{2} \mathrm{O}_{3}$ & $\mathrm{SO}_{3}$ & $\mathrm{Cl}$ & $\mathrm{Na}_{2} \mathrm{O}$ & $\mathrm{K}_{2} \mathrm{O}$ & $\mathrm{PbO}$ & $\mathrm{CeO}_{2}$ & $\mathrm{MnO}$ & $\mathrm{La}_{2} \mathrm{O}_{3}$ & LOI* \\
\hline LGS & 41.20 & 3.69 & 0.288 & 8.61 & 1.23 & 0.44 & 0.07 & 1.10 & 3.85 & 18.65 & 4.72 & 0.32 & 1.78 & 14.03 \\
\hline
\end{tabular}

${ }^{*} \mathrm{LOI}$ loss in ignition was conducted at $950 \pm 50{ }^{\circ} \mathrm{C}$ at $0.5 \mathrm{~h}$ soaking time according to ASTM C114

conditions (Fig. 2). The dissociation of $\mathrm{CaCO}_{3}$ within LGS during thermal treatment and the softening amorphous silicate are the main reasons behind foaming process. $\mathrm{CaCO}_{3}$ is regarded as an internal foaming agent, as it decomposed to yield calcium oxide and carbon dioxide $\left(\mathrm{CO}_{2}\right)$ gas, resulting in the formation of cellular materials (Chen et al. 2012; Praveen Kumar et al. 2015; Saparuddin et al. 2020).

The stereomicroscopic photos (Fig. 3) proved that the size, shape, and number of pores within foamed the materials strongly influenced by sintering temperature, holding time, $\mathrm{NaOH}$ and $\mathrm{CaCl}_{2}$ content, and type of mixing water. At constant holding time $(2 \mathrm{~h})$, the foamed material prepared at $750{ }^{\circ} \mathrm{C}$ exhibits spherical- and elongated-shaped pores with small diameter ranged from 0.22 to $1.90 \mathrm{~mm}$. Increasing sintering temperature up to $800^{\circ} \mathrm{C}$ causes the formation of foamed-LGS containg closed and opened spherical cells with diameter of $0.26-2.55 \mathrm{~mm}$. A significant increase in pore diameter $(0.5-4.09 \mathrm{~mm})$ was detected in the case of foamed material synthesized at $850^{\circ} \mathrm{C}$ and holding time of $2 \mathrm{~h}$. The exposure of LGS to $950^{\circ} \mathrm{C}$ results in structural densification where the lattice structure collapses to a solid with reduced pore size $(0.35-1.13 \mathrm{~mm})$.

At constant sintering temperature $\left(850^{\circ} \mathrm{C}\right)$, increasing holding times ( $1-3 \mathrm{~h}$ ) leads to an increase in pore volume. Additionally, the thermochemical treatment of LGS in the presence of $\mathrm{NaOH}$ (at $850{ }^{\circ} \mathrm{C}$ for $2 \mathrm{~h}$ ) yields foamed materials with pores size larger than that of LGS-foam synthesized in the absence of $\mathrm{NaOH}$. Although the addition of 1 wt. $\% \mathrm{CaCl}_{2}$ increases the pore size, the addition of higher content (up to $5 \mathrm{wt}$. \%) negatively affects the pore growth. Nevertheless, the use of AW in the presence of $3 \mathrm{wt} . \% \mathrm{CaCl}_{2}$ enhances the foaming process.

Table 3 represents the common pores diameters and number of pores within foamed materials. For the samples synthesized at a temperature range of $750-850^{\circ} \mathrm{C}$ in the presence and absence of chemical additives, there is an inverse relationship between pores size and number of pores. The foamed sample with bigger pores size possesses the lower pores number, which is in line with previously published work (Xia et al. 2013). This rule is not applied at high temperature $\left(950^{\circ} \mathrm{C}\right)$, as the low number of small sized pores have been identified. The melting of softened material could be the main reason behind this outcome.
It is undoubted that the emission of $\mathrm{CO}_{2}$ gas and the softening LGS during thermal treatment cause a remarkable increase in the volume of the sintered sample, resulting in a lightweight material with high porosity (Soloki and Esmailian 2015; Rajak et al. 2019; An et al. 2021). Accordingly, there is a strong correlation between volume change, porosity, and bulk density. The sample with the highest porosity exhibits the lowest bulk density and the highest volume expansion. As shown in Fig. 4a, increasing sintering temperature up to $850^{\circ} \mathrm{C}$ has resulted in a remarkable increment in the volume of the sample and porosity, accompanied by a significant reduction in bulk density. A further increase in sintering temperature leads to the formation of relatively dense sample with low porosity and high bulk density. Same trend was observed in the previous findings (Chen et al. 2017; Saparuddin et al. 2020). The change in holding time of at $850{ }^{\circ} \mathrm{C}$ from 1 to $2 \mathrm{~h}$ yields thermally treated sample with higher volume expansion, higher porosity, and lower bulk density (Fig. 4b). The exposure of LGS to the same temperature up to $3 \mathrm{~h}$ causes a slight change in its properties, suggesting the fact that 850 ${ }^{\circ} \mathrm{C}$ and $2 \mathrm{~h}$ are the optimum temperature and holding time, respectively, for foaming process.

Comparing with the foamed material synthesized at $850{ }^{\circ} \mathrm{C}$ for $2 \mathrm{~h}$ holding time, the addition of $1 \mathrm{wt} . \%$ $\mathrm{NaOH}$ results in a considerable change in volume (500 to $605 \%)$, bulk density $\left(0.3-0.25 \mathrm{~g} / \mathrm{cm}^{3}\right)$, and porosity (85.3-91.4\%) (Fig. 4c). A slight change in these values has been recorded when the LGS sintered in the presence of higher $\mathrm{NaOH}$ contents ( 3 and 5 wt. \%). Like $\mathrm{NaOH}$ with 1 wt.\%, the use of $\mathrm{CaCl}_{2}$ with the same content also significantly improved the properties of the produced LGS-foam (Fig. 4d). A further increase in $\mathrm{CaCl}_{2}$ causes a negative effect on the foaming process, including the retardation of volume change, reduction of porosity, and increasing bulk density. Using AW as a mixing water to the sample having $3 \mathrm{wt} . \% \mathrm{CaCl}_{2}$ was found to produce foaming materials with higher volume and porosity as well as lower bulk density (Fig. 4e).

Thermal conductivity is regarded as one of the main parameters which measure the capability of porous materials for insulating the heat (Ge and Zheng 2020; Assefi et al. 2021). It is well known that the thermal conductivity mainly depends on the porosity of foamed 
Fig. 2 Digital photos of LGS foams synthesized at different conditions

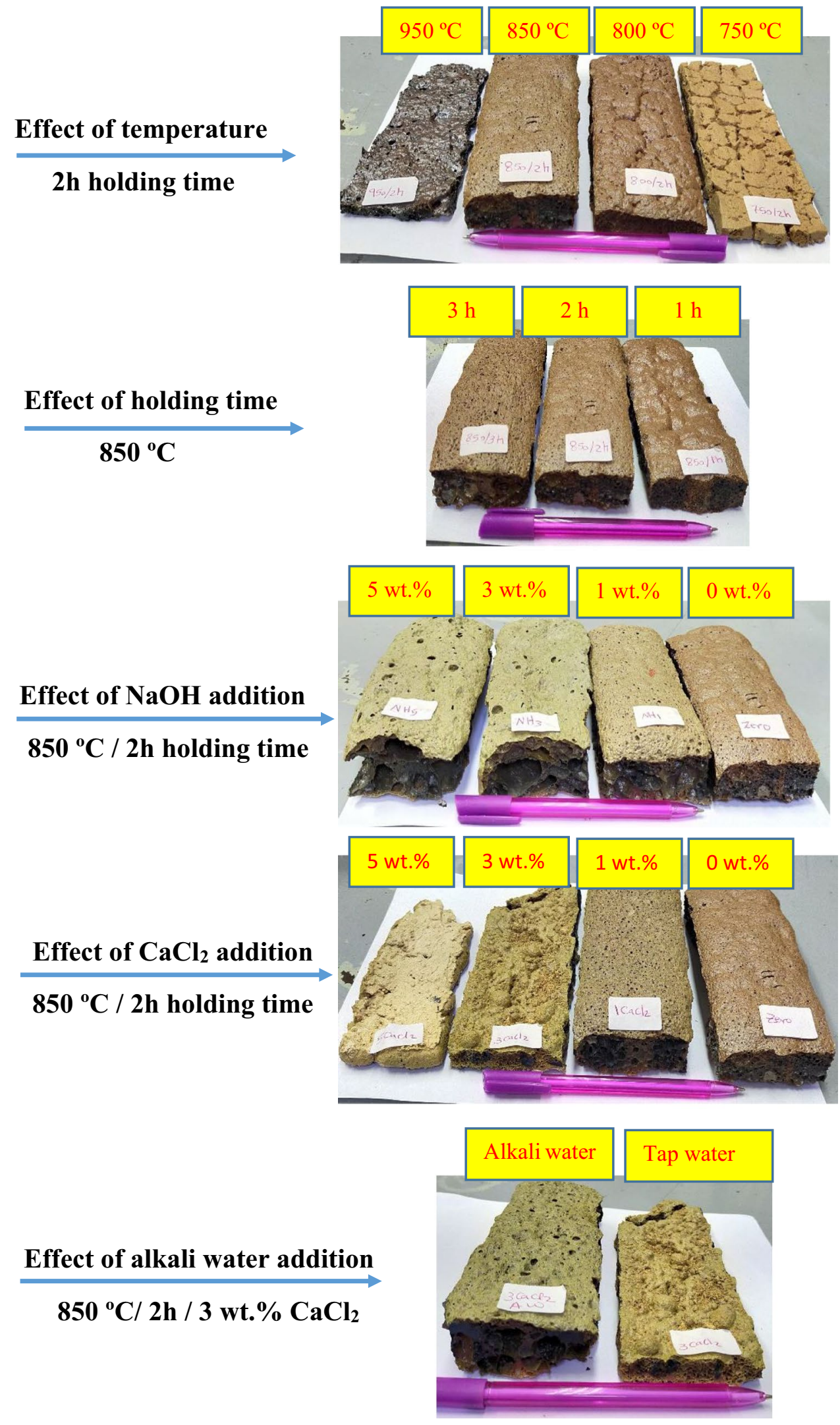


material, as the sample with highest porosity shows the highest thermal insulation (Haihui et al., 2017; Hassan et al. 2018; König et al. 2018). Herein, other parameters such as common pores diameter and closed cells percentage within foamed materials were represented in Fig. 5(a-e). A reverse relationship between thermal conductivity, closed cells percentage and common pores diameter has been detected. Increasing pores diameter and closed cells content materially decreased the thermal conductivity value. This can be explained by following facts (König et al. 2019): As the movements of air or $\mathrm{CO}_{2}$ gas entrapped by closed cells are restricted, the increased closed cells content inhibit heat transfer by convection through the cellular structure. Furthermore, the increase in pore diameter of foamed material with a homogeneous pore structure results in decreasing the pore walls solid volume and hence limiting the heat transfer by conduction and radiation.

Rising sintering temperature up to $850{ }^{\circ} \mathrm{C}$ results in the increase of closed cells content and diameter of pores accompanied by thermal conductivity reduction. However, the exposure of LGS to $950{ }^{\circ} \mathrm{C}$ causes an opposite effect in which a dense structure has been obtained (Fig. 5a). The holding time was found to have a significant effect on thermal conductivity reduction, common pores diameter and closed cells $\%$ increment (Fig. 5b). The increase of exposure time results in the dissociation of greater amount of $\mathrm{CaCO} 3$ and hence the release of more $\mathrm{CO} 2$ gas. Owing to the lower thermal conductivity of $\mathrm{CO}_{2}$ enclosed within cells/ pores than static air (Vesovic et al., 1992), it contributes to the reduced in thermal conductivity of foamed-LGS. The same trend was recorded with increasing $\mathrm{NaOH}$ addition (Fig. 5c). Interstingly, the addition of $1 \mathrm{wt} . \% \mathrm{CaCl}_{2}$ causes the formation of foamed-LGS with lower thermal conductivity escorted by higher closed cells\% and larger common pores diameter than those of foamed material without $\mathrm{CaCl}_{2}$ at the same sintering temperature and holding time (Fig. 5d). The continuation of $\mathrm{CaCl}_{2}$ addition yields foamed-LGS with higher thermal conductivity, lower pores diameter and lower closed cells percentage. Nevertheless, the use of AW as alternative to TW in LGS having $3 \mathrm{wt} . \% \mathrm{CaCl}_{2}$ enhances the thermal insulation of the produced foamed material, which associated with the formation of closed cells with higher diameter (Fig. 5e).

\section{$\mathrm{Pb}$-leaching from foamed materials}

Apart from the variations in $\mathrm{Pb}$-concentrations, all values are below the safe limit of characteristic leaching procedure (TCLP: $\leq 5 \mathrm{mg} / \mathrm{l}$ ) (Table 4). The untreated sample represents $\mathrm{Pb}$-concentration of $93 \mathrm{mg} / \mathrm{l}$. The exposure of LGS to different elevated temperatures decreases the leachability of $\mathrm{Pb}$. Specifically, the foamed materials sintered at $750,800,850$, and $950{ }^{\circ} \mathrm{C}$ demonstrate $\mathrm{Pb}$ concentration of $3.75,3.01,2.12$, and $1.78 \mathrm{mg} / 1$ with immobilization\% of $95.98,96.77,97.72$, and $98.09 \%$, respectively. Increasing holding time from 1 to $3 \mathrm{~h}$ at the sintering temperature of $850^{\circ} \mathrm{C}$ decreases the $\mathrm{Pb}$-concentration from 2.78 to $2.03 \mathrm{mg} / \mathrm{l}$. A significant decrease in $\mathrm{Pb}$-concentration was recorded when the foaming process takes place in the presence of $\mathrm{NaOH}$ and $\mathrm{CaCl}_{2}$. The foamed materials having $\mathrm{CaCl}_{2}$ showed the lowest $\mathrm{Pb}$-concentrations. A slight reduction in $\mathrm{Pb}$-leachability was got when $\mathrm{CaCl}_{2}$ dissolved in $\mathrm{AW}$ before sintering process.

Table 4 also shows that the $\mathrm{Pb}$-fractions (Pb-concentrations in different leachates) of the foamed-LGS immersed in different media. Sintering LGS at 750 ${ }^{\circ} \mathrm{C}$ leads to the transformation of all exchangeable $\mathrm{Pb}$ fraction and $\mathrm{Pb}$ bound to organic matter to non-bioavailable $\mathrm{Pb}$. Additionally, a significant decrease in the concentration of acid soluble $\mathrm{Pb}$ was recorded. A continues decrease in acid soluble $\mathrm{Pb}$-fraction accompanied by a remarkable increment in non-bioavailable $\mathrm{Pb}$ was observed by rising temperature and by elongating sintering time. Although the addition of $\mathrm{NaOH}$ induces the transformation of low stable acid-soluble fraction into non-bioavailable $\mathrm{Pb}$-fraction with higher stability, the use of $\mathrm{CaCl}_{2}$ shows the highest effect at all addition levels. Using AW, as a mixing water before sintering process, causes a marginal change in both acid soluble and non-bioavailable $\mathrm{Pb}$-fractions within sintered-LGS having $3 \mathrm{wt} . \% \mathrm{CaCl}_{2}$, indicating that the type of water has low effectiveness in $\mathrm{Pb}$-stabilization within sintered LGS-CaCl${ }_{2}$ system. It is recommended that, the volatized $\mathrm{Pb}$ as $\mathrm{PbCl}_{2}$ should be collected in seal vessel containing $\mathrm{CO} 2$ to yield cerussite and hydrocerussite phases with higher stability..

First-order kinetic reaction was detected by plotting $\mathrm{ln}$ $\mathrm{Cx} / \mathrm{Ci}(\mathrm{Ci}$ and $\mathrm{Cx}$ are the $\mathrm{Pb}$-concentrations before and after sintering process, respectively) as a function of temperature, holding time, and $\mathrm{NaOH}$ and $\mathrm{CaCl}_{2}$ contents (Fig. 6a-d). The simple statistical model shows that the effect of sintering temperature represents rate constant $(\mathrm{K})$ value $(0.254)$ higher than that of holding time $(0.159)$. Incorporating $\mathrm{NaOH}$ was found to increase the $K$-value (0.378); however, $\mathrm{CaCl}_{2}$ has a higher effect (0.666). As a rule, $K$-value is beneficially used to identify the impact of the independence parameters on the Pb-stabilization and/ or removal. The higher the $K$-value, the higher the effect of the independence parameter on the $\mathrm{Pb}$-stabilization/removal (Abdel-Gawwad et al. 2020b). The effectiveness of such parameters on the immobilization/removal process can be ordered as follows: $\mathrm{CaCl}_{2}>\mathrm{NaOH}>$ sintering temperature $>$ holding time. 

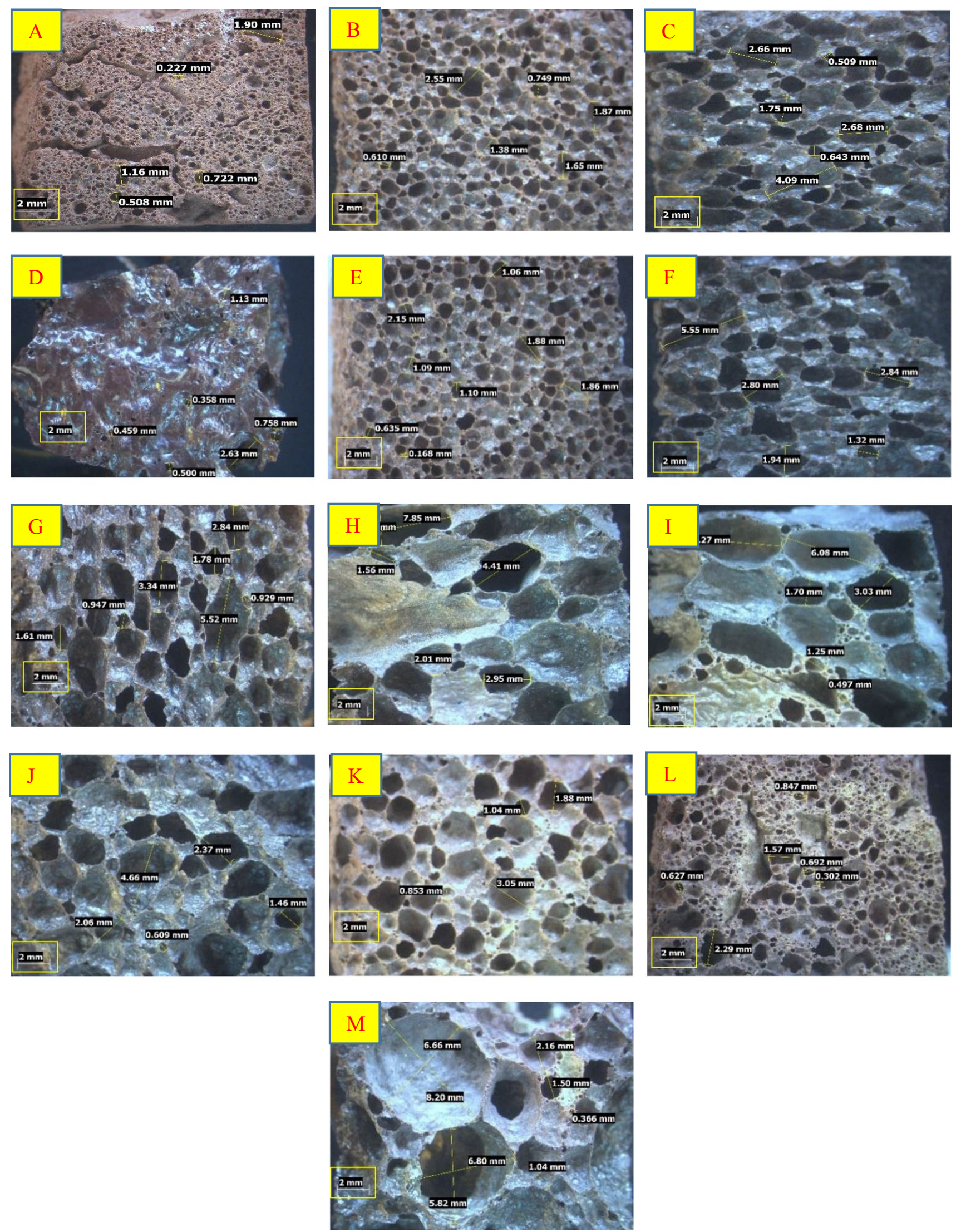
4 Fig. 3 Stereomicroscopic photos of foamed LGS samples synthesized at $750-950{ }^{\circ} \mathrm{C}$ for $2 \mathrm{~h}$ holding time (A-D), at $850{ }^{\circ} \mathrm{C}$ for 1 and $3 \mathrm{~h}$ holding time ( $\mathbf{E}$ and $\mathbf{F}$, respectively), at $850^{\circ} \mathrm{C}$ for $2 \mathrm{~h}$ holding time in the presence of 1,3 , and $5 \mathrm{wt} . \% \mathrm{NaOH}(\mathbf{G}, \mathbf{H}$, and $\mathbf{I}$, respectively), at $850^{\circ} \mathrm{C}$ for $2 \mathrm{~h}$ holding time in the presence of 1,3 , and $5 \mathrm{wt} . \% \mathrm{CaCl}_{2}$ (J, K, and $\mathbf{L}$, respectively), and at $850^{\circ} \mathrm{C}$ for $2 \mathrm{~h}$ holding time in the presence of $3, \mathrm{CaCl}_{2}$ dissolved in $\mathrm{AW}(\mathbf{M})$

\section{Discussion}

The transformation of hazardous LGS into safely used thermally insulating product via sintering/chlorination process is the main goal of this work. DT-curve (Fig. 7) shows that the organic matter within LGS completely dissociates at $500{ }^{\circ} \mathrm{C}$; meanwhile, $\mathrm{CaCO}_{3}$ decomposes at a temperature range of $700-840{ }^{\circ} \mathrm{C}$. The LGS was completely softened at $840{ }^{\circ} \mathrm{C}$. Therefore, the organic matter does not contribute to the foaming process, as the gas resulted from the decomposition of organic matter sublimates before LGS-softening. Accordingly, the foaming process strongly influenced by synergistic $\mathrm{CaCO}_{3}$-calcination and silicate- softening. The sintering temperature of $850{ }^{\circ} \mathrm{C}$ offers the favorable conditions for supplementing the decarbonation and softening processes accompanied by the formation of foamed materials with high volume, high porosity, low bulk density and low thermal conductivity. Nevertheless, an opposite effect were detected when the sintering temperature increases up to $950{ }^{\circ} \mathrm{C}$, which could be explained by the transformation of softened material to molten one, yielding material with low-volume change, low porosity, high bulk density, and high thermal conductivity.

The exposure of LGS to elevated temperature not only yields foamed materials with highly thermal insulating property but also strongly affects the reduction of free $\mathrm{Pb}$ within LGS. Several previously published works (Nikolić et al. 2014; Wang et al. 2020; Abdel-Gawwad et al. 2020c; Long et al. 2021) proved that the $\mathrm{Pb}$-leaching strongly influenced by the compaction and porosity of the hardened materials. The hardened material with the highest compressive strength and lowest porosity exhibits the highest efficiency in $\mathrm{Pb}$-immobilization. An opposite trend was detected in the present work, as $\mathrm{Pb}$-leaching not influenced by the porosity and compressive strength of the produced foamed-materials (Fig. 8a-d).

To shed more light on the reasonable reason behind the low Pb-leaching from highly porous foamed-LGS, the XRD-analysis was conducted on the sintered LGS at different conditions. Figure 9a shows that the intensity of $\mathrm{CaCO}_{3}$ decreases after the exposure of LGS to $750{ }^{\circ} \mathrm{C}$, indicating the partial decomposition of $\mathrm{CaCO}_{3}$. No calcium oxide (resulted from calcination of $\mathrm{CaCO}_{3}$ ) peaks have been detected but new reflections affiliated to ganomalite phase $\mathrm{Pb}_{9} \mathrm{Ca}_{5} \mathrm{MnSi}_{9} \mathrm{O}_{33}$ have been observed. This means that the $\mathrm{CaO}$ resulted from the calcination of $\mathrm{CaCO}_{3}$ consumed in the formation of crystalline ganomalite phase. Increasing temperature has resulted in the disappearance of $\mathrm{CaCO}_{3}$-peak, the reduction of silicon peak, and an enhancement in ganomalite peak intensity. Interstingly, the reduction of silicon could be caused by the oxidation reaction at elevated temperatures to yield silicon dioxide (Nguyen 2011; Gerlach and Maser 2016), which could contribute to the formation of ganomalite phase.

As stated by Nowak et al. (2012); Yu et al., (2013), Wang et al., (2017); Li et al., (2019), the use of chloride salts $\left(\mathrm{NaCl}\right.$ and/or $\left.\mathrm{CaCl}_{2}\right)$ as an additive to $\mathrm{Pb}$-contaminated-soil was found to be more effective in $\mathrm{Pb}$-removal through chlorination and volatilization process. This explains the continuous reduction of $\mathrm{Pb}$-leaching after the addition of $\mathrm{CaCl}_{2}$ to LGS before thermal treatment. Based on chlorination/volatilization process, the evaporated $\mathrm{PbCl}_{2}$ could contribute to the foaming process like $\mathrm{CO}_{2}$ resulted from $\mathrm{CaCO}_{3}$ calcination. These outcomes confirmed that the low leaching of $\mathrm{Pb}$ from sintered-LGS is caused by the positive effect of thermal treatment on $\mathrm{Pb}$ stabilization (through the formation of ganomalite phase with high stability) and $\mathrm{Pb}$-removal (through the chlorination/volatilization of $\mathrm{Pb}$ ).

As confirmed by XRD-analysis (Fig. 9b), the addition of $\mathrm{CaCl}_{2}$ enhances the formation of tri-calcium di-silicate $\left(\mathrm{Ca}_{3} \mathrm{Si}_{2} \mathrm{O}_{7}\right)$ phase at the expense of ganomalite one (responsible for $\mathrm{Pb}$-stabilization). Nevertheless, increasing $\mathrm{CaCl}_{2}$ addition greatly decreased $\mathrm{Pb}$-leaching. This should be explained by the decrease of free $\mathrm{Pb}$-availability, which associated with the high efficiency of $\mathrm{CaCl}_{2}$ in the removal of $\mathrm{Pb}$ through the enhancement of chlorination/evaporation process. Although it enhances the Pb-removal, the

Table 3 Common pore diameter and number of pores within foamedLGS mixtures of $4 \mathrm{~cm}^{2}$ area

\begin{tabular}{llc}
\hline Mixture notation & $\begin{array}{l}\text { Common pore } \\
\text { diameter, mm }\end{array}$ & Number of pores \\
\hline F-LGS-750 (2 h) & 0.43 & 2775.00 \\
F-LGS-800 (2 h) & 0.75 & 391.00 \\
F-LGS-850 (1 h) & 1.02 & 315.00 \\
F-LGS-850 (2 h) & 1.75 & 118.00 \\
F-LGS-850 (3 h) & 1.94 & 98.00 \\
F-LGS-950 (2 h) & 0.36 & 69.00 \\
F-LGS-850 (2 h)-SH1 & 2.31 & 99.00 \\
F-LGS-850 (2 h)-SH3 & 3.03 & 59.00 \\
F-LGS-850 (2 h)-SH5 & 4.15 & 20.00 \\
F-LGS-850 (2 h)-CC1 & 2.37 & 58.00 \\
F-LGS-850 (2 h)-CC3 & 1.04 & 118.00 \\
F-LGS-850 (2 h)-CC5 & 0.62 & 760.00 \\
F-LGS-850 (2 h)-CC3 / AW & 4.28 & 20.00 \\
\hline
\end{tabular}



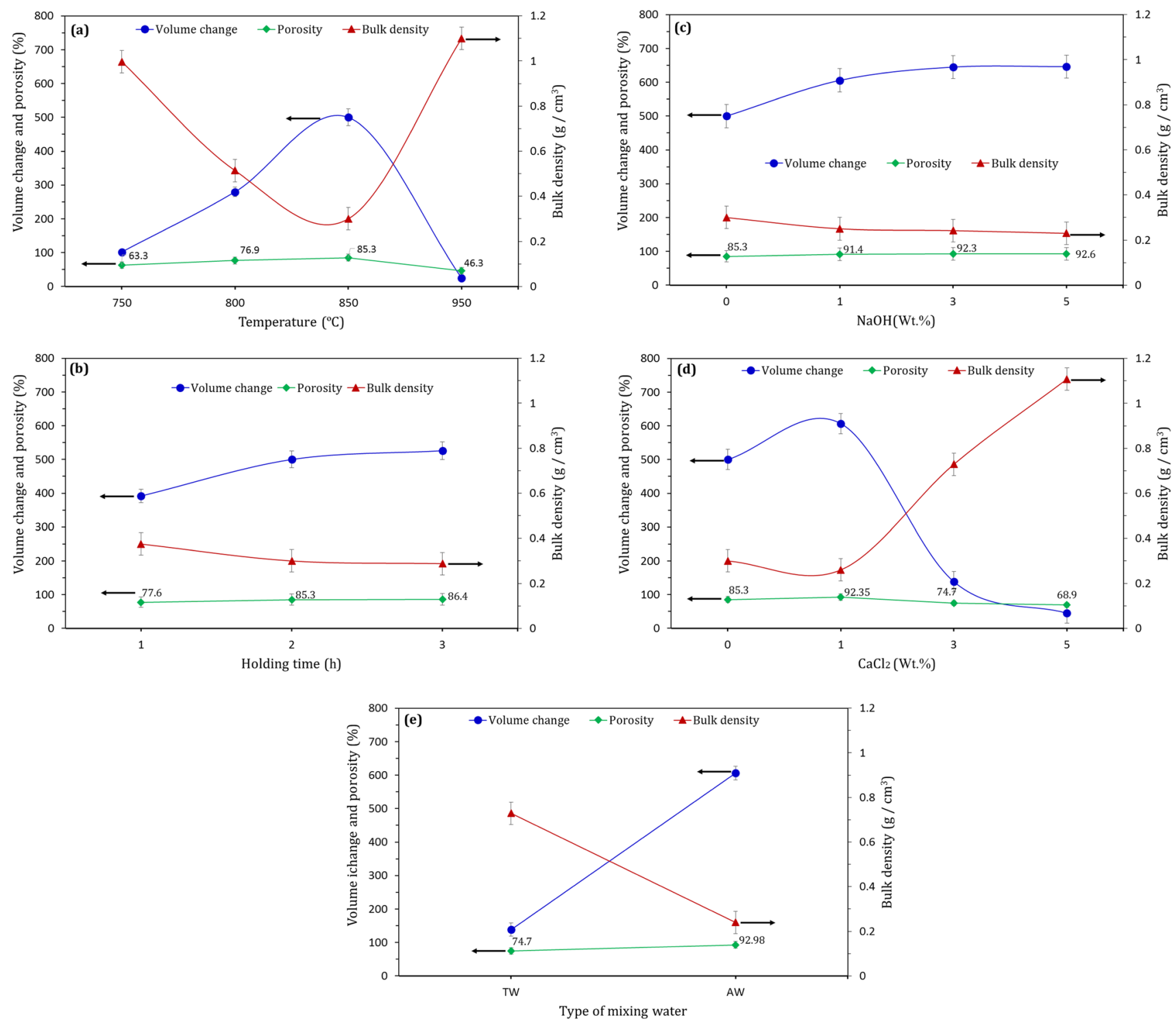

Fig. 4 Relationship between volume change, porosity, and bulk density of foamed glass synthesized at (a) different sintering temperatures at $2 \mathrm{~h}$ holding time, (b) $850^{\circ} \mathrm{C}$ for different holding times, (c \& d) $850^{\circ} \mathrm{C}$ and $2 \mathrm{~h}$ holding time in the presence of different $\mathrm{NaOH}$ and

high content of $\mathrm{CaCl}_{2}$ causes the retardation of foaming process, yielding high dense/low porous foamed materials. This ascribed to the formation of calcium silicate phase with higher sintering temperature (Zhou et al. 2017). Utilizing $\mathrm{AW}$ as a solvent for $\mathrm{CaCl}_{2}$ instead of TW was found to enhance the foaming process, suggesting the AW acts as fluxing material which decreases the sintering temperature of LGS- $\mathrm{CaCl}_{2}$ system.

Regardless of $\mathrm{NaOH}$ (as one of the common fluxing materials) enhances the softening and foaming process under thermal load, it also significantly decreases the $\mathrm{Pb}$-concentrations in leachates. All sintered LGS synthesized in the presence of $\mathrm{NaOH}$ represent the same
$\mathrm{CaCl}_{2}$ contents, respectively, and (e) $850{ }^{\circ} \mathrm{C}$ and $2 \mathrm{~h}$ holding time in the presence of 3 wt. $\% \mathrm{CaCl}_{2}$ individually dissolved in $\mathrm{TW}$ and $\mathrm{AW}$ before sintering process

features, including reducing silicon peak with the formation of ganomalite phase (Fig. 9b). Nevertheless, a new phase affiliated to potassium sodium aluminosilicate was observed. $\mathrm{NaOH}$ was found to have high efficiency in the dissolution of amorphous silicate network, yielding reactive silicate species which easily interacts with free $\mathrm{Pb}$ to yield lead silicate with high stability, as in line with previously published works (Abdel-Gawwad et al. 2019). Although the effectiveness of $\mathrm{NaOH}$ in the enhancement of foaming process and in the immobilization of $\mathrm{Pb}$, it exhibits high environmental pollution. Each tonne of $\mathrm{NaOH}$ generates approximately 1.91-3.18 tonnes $\mathrm{CO}_{2}$ (Turner and Collins 2013; McLellan et al. 2011). The 

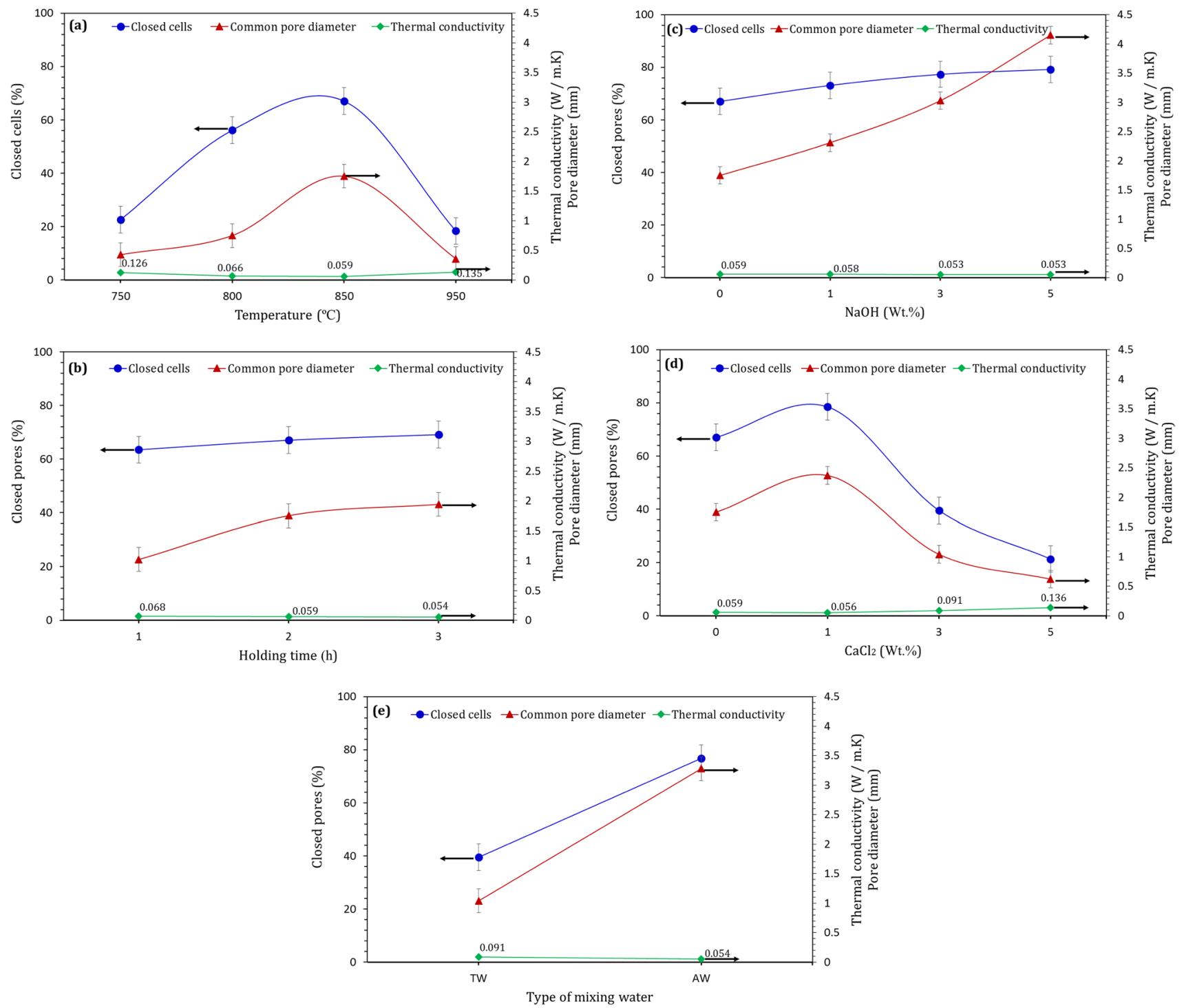

Fig. 5 Relationship between thermal conductivity, common pore diameter, and closed cells percentage of foamed glass synthesized at (a) different sintering temperatures at $2 \mathrm{~h}$ holding time, (b) $850{ }^{\circ} \mathrm{C}$ for different holding times, (c \& d) $850{ }^{\circ} \mathrm{C}$ and $2 \mathrm{~h}$ holding time in

utilization of $\mathrm{AW}$, as an alternative to $\mathrm{NaOH}$, not only decreases the $\mathrm{CO}_{2}$ emission but also reduced the processing cost of the fabricated foams.

The inferior thermal conductivity coefficients of the foamed-LGS composites point out their superior thermal resistivity. All the composites sintered at 800 and $850{ }^{\circ} \mathrm{C}$ with and without additives $\left(\mathrm{NaOH}\right.$ or $\left.\mathrm{CaCl}_{2}\right)$ possessed thermal conductivity values $\leq 0.1 \mathrm{~W} / \mathrm{m} . \mathrm{K}$ (prescribed limit of thermal insulation); however, the composite sintered at $850^{\circ} \mathrm{C}$ for $3 \mathrm{~h}$ exhibited the lowest thermal conductivity $(0.054 \mathrm{~W} / \mathrm{m} . \mathrm{K})$; i.e., generally they can be classified as good thermal insulators and recommended for various applications in the thermal insulation of buildings. The significantly reduced thermal conductivity with the the presence of different $\mathrm{NaOH}$ and $\mathrm{CaCl}_{2}$ contents, respectively, and (e) $850{ }^{\circ} \mathrm{C}$ and $2 \mathrm{~h}$ holding time in the presence of $3 \mathrm{wt} . \% \mathrm{CaCl}_{2}$ individually dissolved in TW and AW before sintering process

reasonable compressive strength and adequate thermal stability could point out the enhanced durability; these findings could explain the competitive advantages of the developed novel composites over the organic foam materials like (polystyrene, polyurethane, etc.) which lack of sufficient mechanical strength and suffer from low melting temperature.

\section{Conclusions}

In this study, the successful synthesis of well-defined and homogeneous porous foamed glass with minimum to nondetectable levels of $\mathrm{Pb}$-leaching has been attained using a 
Table $4 \mathrm{~Pb}$-leaching behavior of LGS and the synthesized foamed LGS through sintering process at different conditions

\begin{tabular}{|c|c|c|c|c|c|c|}
\hline \multirow[t]{2}{*}{ Mixture notation } & \multirow{2}{*}{$\begin{array}{l}\mathrm{Pb} \text {-concentration, } \\
\mathrm{mg} / \mathrm{l}\end{array}$} & \multirow{2}{*}{$\begin{array}{l}\text { Immobiliza- } \\
\text { tion, \% }\end{array}$} & \multicolumn{4}{|l|}{$\mathrm{Pb}$-fractions, $\%$} \\
\hline & & & Exchangeable & $\begin{array}{l}\text { Bound to } \\
\text { organic }\end{array}$ & Acid soluble & Non bioavailable \\
\hline LGS & 93.18 & 0.00 & 9.22 & 6.52 & 20.62 & 63.64 \\
\hline F-LGS-750 (2 h) & 3.75 & 95.98 & - & - & 8.25 & 91.75 \\
\hline F-LGS-800 (2 h) & 3.01 & 96.77 & - & - & 6.05 & 93.95 \\
\hline F-LGS-850 (1 h) & 2.79 & 97.00 & - & - & 7.03 & 92.97 \\
\hline F-LGS-850 (2 h) & 2.22 & 97.61 & - & - & 4.13 & 95.87 \\
\hline F-LGS-850 (3 h) & 2.03 & 97.82 & - & - & 3.94 & 96.06 \\
\hline F-LGS-950 (2 h) & 1.78 & 98.09 & - & - & 3.68 & 96.32 \\
\hline F-LGS-850 (2 h)-SH1 & 1.53 & 98.35 & - & - & 2.25 & 97.75 \\
\hline F-LGS-850 (2 h)-SH3 & 0.87 & 99.06 & - & - & 1.45 & 98.55 \\
\hline F-LGS-850 (2 h)-SH5 & 0.76 & 99.18 & - & - & 1.38 & 98.62 \\
\hline F-LGS-850 (2 h)-CC1 & 0.99 & 98.93 & - & - & 1.01 & 98.99 \\
\hline F-LGS-850 (2 h)-CC3 & 0.51 & 99.45 & - & - & 0.51 & 99.49 \\
\hline F-LGS-850 (2 h)-CC5 & 0.30 & 99.67 & - & - & 0.36 & 99.64 \\
\hline F-LGS-850 (2 h)-CC $3 / \mathrm{AW}$ & 0.12 & 99.87 & - & - & 0.29 & 99.71 \\
\hline
\end{tabular}

rapid and facile method. Lead glass sludge is composed of amorphous lead silicate materials with considerable calcium carbonate content, which acts as interior foaming agent. several findings can be concluded as follows:
(1) The exposure of lead glass sludge to elevated temperature (sintering) has resulted in the formation of porous foamed material with low Pb-leachability. Additionally, the immobilization process was induced by the inter-
Fig. 6 Lin $\mathrm{Cx} / \mathrm{Ci}$ values as a function of (a) sintering temperatures, (b) holding times, and $(\mathbf{c} \& \mathbf{d}) \mathrm{NaOH}$ and $\mathrm{CaCl}_{2}$ contents, respectively
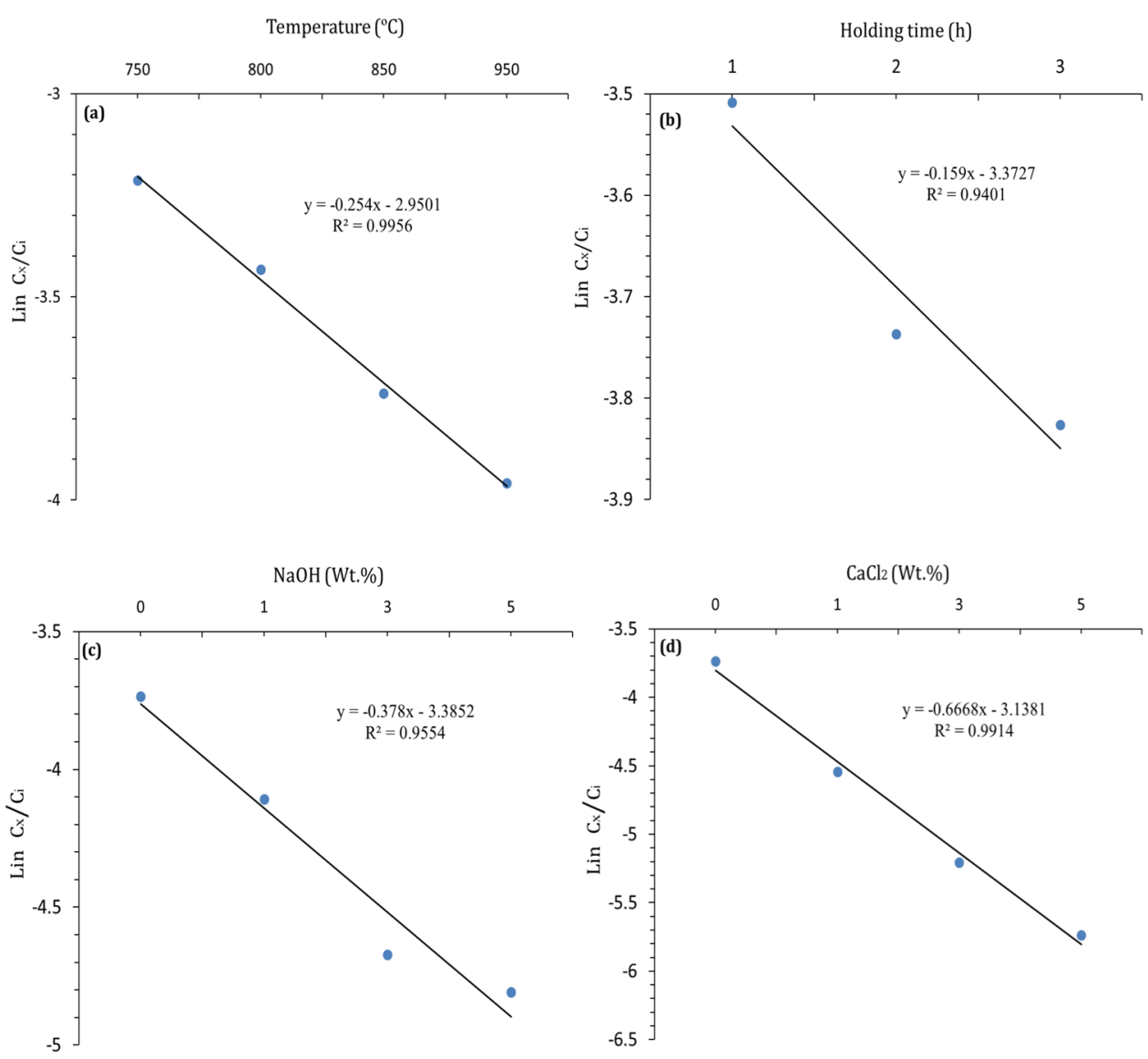


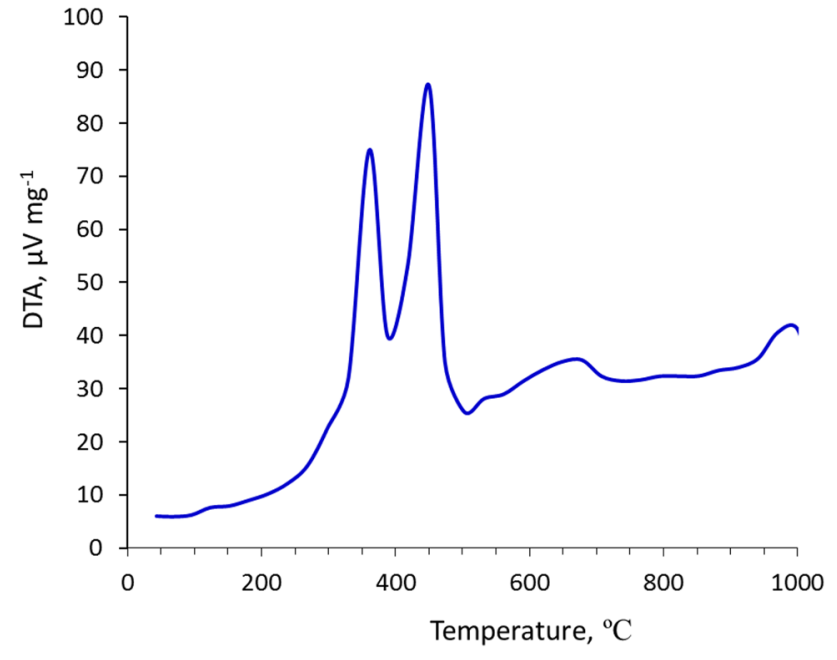

Fig. 7 DT-curve of LGS

action of free lead and amorphous silicate within lead glass sludge with calcium oxide (resulted from calcium carbonate calcination) to yield insoluble ganomalite mineral with high stability as confirmed by X-ray diffraction.
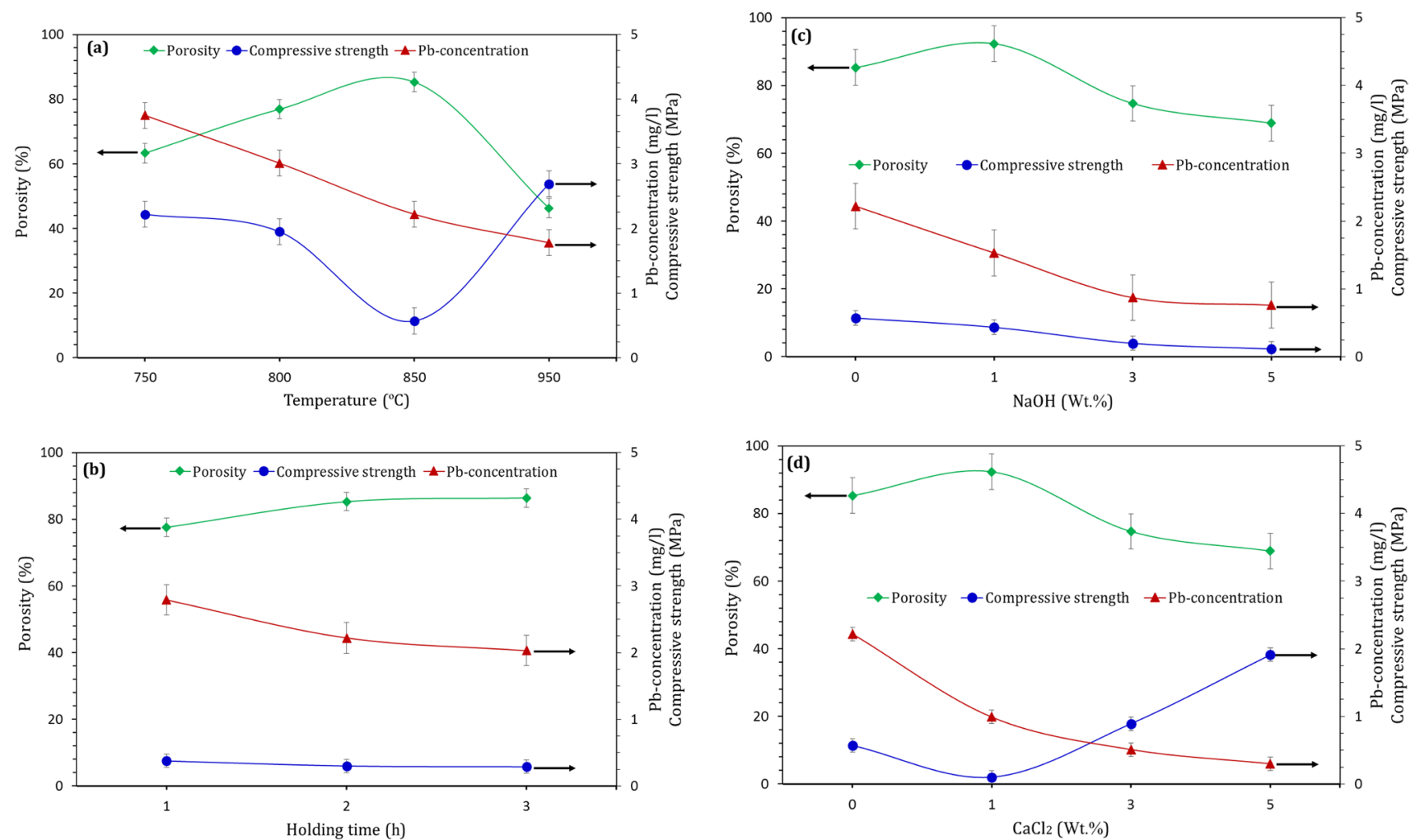

(2) The simple kinetic model proved that calcium chloride addition showed the highest efficiency in the reduction of $\mathrm{Pb}$-leaching via synergistic stabilization (by the formation insoluble ganomalite) and chlorination/ vaporization (by the formation of $\mathrm{PbCl}_{2}$ ) process. Nevertheless, adding high calcium chloride content has a negative impact on foaming process which associated with the formation of calcium silicate mineral.

(3) Increasing sodium hydroxide addition enhanced the foaming process and $\mathrm{Pb}$-immobilization. Alkali wastewater has been successfully used as an alternative to sodium hydroxide because it enhanced the foaming process of lead glass sludge system containing $3 \mathrm{wt}$. \% calcium chloride. Tuning the pore size and structure of the foamed glass is doable via varying sintering conditions and foaming agent content.

(4) Thermal conductivity of the produced foamed glass mainly influenced by the type of pores (closed or open), pore size, and pore distribution. The thermal conductivity values are within the prescribed limits for thermal insulation materials.

(5) The experimental results did not reveal a correlation between the porosity of the synthesized foamed glass and $\mathrm{Pb}$-leachability, suggesting the fact that the trans-

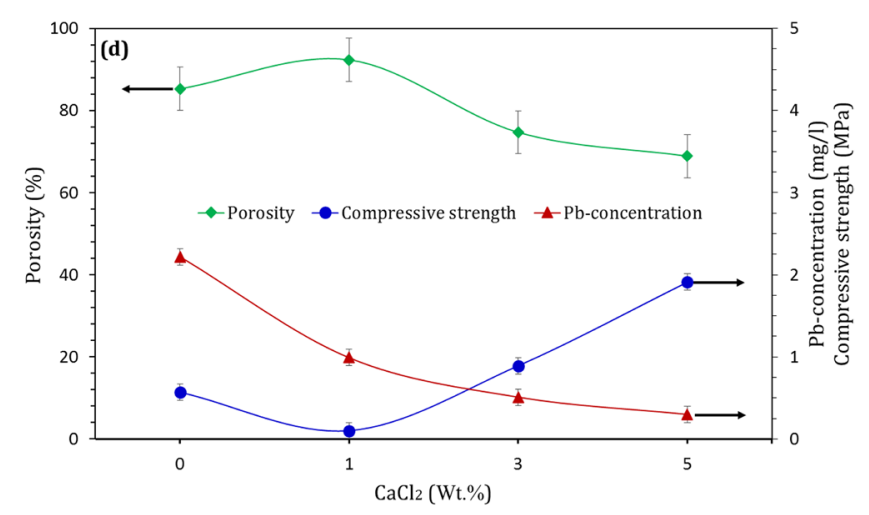

Fig. 8 Relationship between $\mathrm{Pb}$-concentration, compressive strength, and porosity of foamed glass synthesized at (a) different sintering temperatures, (b) different holding times, and $\left(\mathbf{c} \&\right.$ d) different $\mathrm{NaOH}$ and $\mathrm{CaCl}_{2}$ contents, respectively 

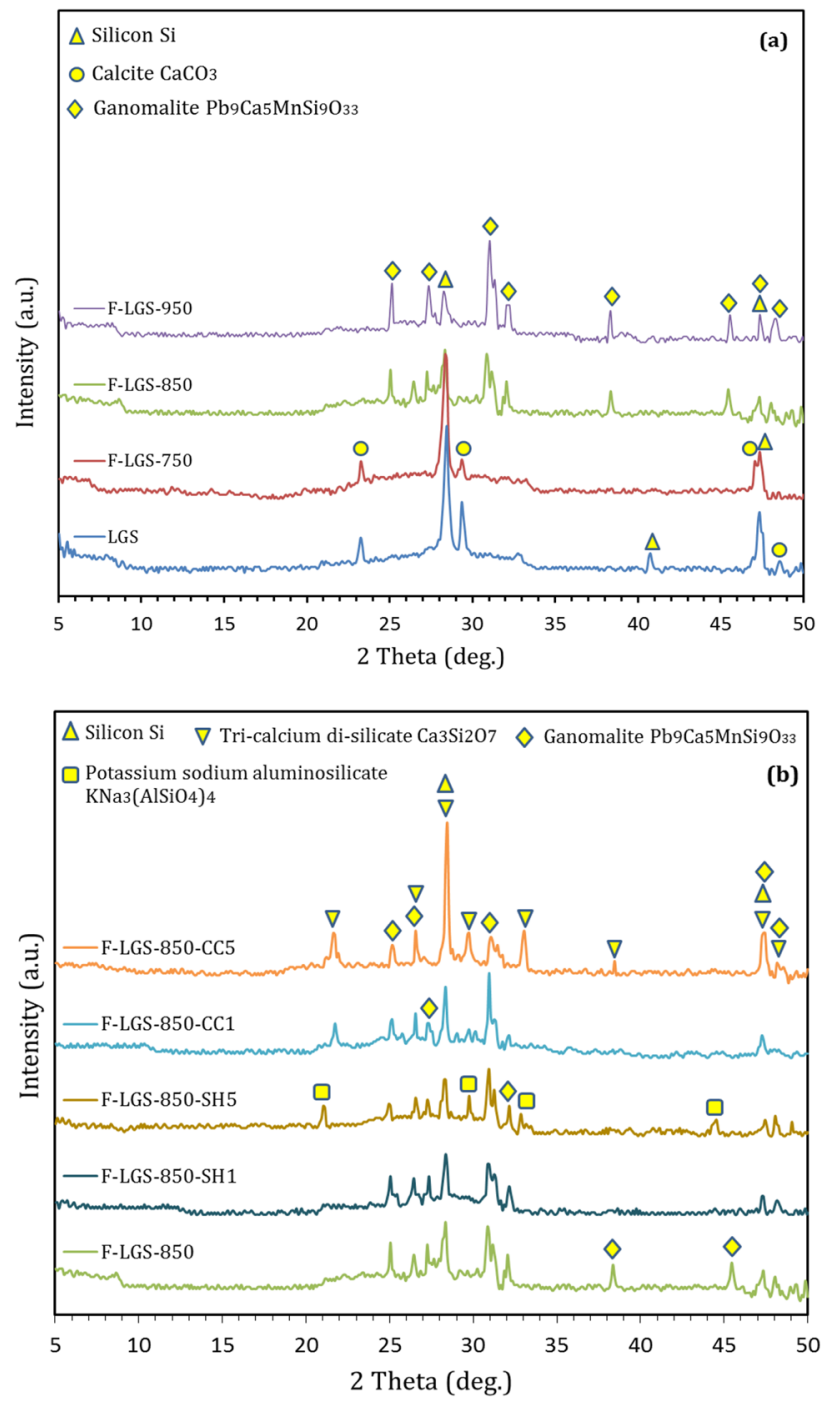

Fig. 9 XRD-patterns of foamed materials fabricated at (a) different elevated temperatures and (b) in the presence different $\mathrm{NaOH}$ and $\mathrm{CaCl}_{2}$ contents

formation of exchangeable $\mathrm{Pb}$ into insoluble $\mathrm{Pb}$-containing-phase is the dominant immobilization mechanism.

(6) The obtained results indicate that the newly developed foamed glass composites are of great importance and may be adopted for thermal insulation in several applications.

(7) Although the proposed method showed the high efficiency in the immobilization/removal $\mathrm{Pb}$, it represents a main shortcoming as the sublimated $\mathrm{PbCl}_{2}$ through sintering process causes an environmental problem. It recommended to design an innovative system to control in the vaporized toxic gas.
Acknowledgements The authors would like to thank all members of Raw Building Materials and Processing Technology Research Institute and Building Physics Institute for their support.

Author contribution Hamdy A. Abdel-Gawwad: Methodology; Writing original article; revision.

Mona S. Mohammed: Data curation; Formal analysis; Methodology. Mohammed Arif: Methodology; Data curation; Formal analysis.

Hamada Shoukry: Methodology; Writing original article; revision.

Funding Open access funding provided by The Science, Technology \& Innovation Funding Authority (STDF) in cooperation with The Egyptian Knowledge Bank (EKB).

Data availability All data and materials will be available upon request.

\section{Declarations}

Ethics approval Not applicable.

Consent to participate Not applicable.

Consent for publication All authors agree about submission to the journal.

Competing interests The authors declare no competing interests.

Open Access This article is licensed under a Creative Commons Attribution 4.0 International License, which permits use, sharing, adaptation, distribution and reproduction in any medium or format, as long as you give appropriate credit to the original author(s) and the source, provide a link to the Creative Commons licence, and indicate if changes were made. The images or other third party material in this article are included in the article's Creative Commons licence, unless indicated otherwise in a credit line to the material. If material is not included in the article's Creative Commons licence and your intended use is not permitted by statutory regulation or exceeds the permitted use, you will need to obtain permission directly from the copyright holder. To view a copy of this licence, visit http://creativecommons.org/licenses/by/4.0/.

\section{References}

Abdel-Gawwad HA, Abd El-Aleem S, Zayed A (2021) Stabilization of hazardous lead glass sludge using reactive magnesia via the fabrication of lightweight building bricks. J Hazardous Mater 403:124017

Abdel-Gawwad HA, Hussein HS, Mohammed MS (2020a) Bioremoval of $\mathrm{Pb}, \mathrm{Cu}$, and $\mathrm{Ni}$ from solutions as nano-carbonates using a plant-derived urease enzyme-urea mixture. Environ Sci Pollut Res 27:30741-30754

Abdel-Gawwad HA, Mohamed SA, Mohammed MS (2019) Recycling of slag and lead-bearing sludge in the cleaner production of alkali activated cement with high performance and microbial resistivity. J Clean Prod 220:568-580

Abdel-Gawwad HA, Mohammed MS, Ads EN (2020) A novel eco-sustainable approach for the cleaner production of readymix alkali activated cement using industrial solid wastes and organic-based activator powder. J Clean Prod 256:120705 
Abdel-Gawwad HA, Mohammed MS, Zakey SE (2020) Preparation, performance, and stability of alkali-activated-concrete wastelead-bearing sludge composites. J Clean Prod 259:120924

Al-Jabri K, Shoukry H, Mokhtar MM, Morsy MS (2021) Thermophysical, mechanical and microstructural properties of cementless lightweight mortar. Adv Cem Res 33(2):74-83

An J, Chen C, Zhang M (2021) Effect of CaCO3 content change on the production of closed-cell aluminum foam by selective laser melting. Optics \& Laser Technology 141:107097

Assefi M, Maroufi S, Mansuri I, Sahajwalla V (2021) High strength glass foams recycled from LCD waste screens for insulation application. J Clean Prod 280:124311

ASTM C109 / C109M - 20b .Standard Test Method for Compressive Strength of Hydraulic Cement Mortars (Using 2-in. or [50 mm] Cube Specimens) (2020)

ASTM C303 - 21. Standard Test Method for Dimensions and Density of Preformed Block and Board-Type Thermal Insulation (2021)

ASTM D5334-14 Standard Test Method for Determination of Thermal Conductivity of Soil and Soft Rock by Thermal Needle Probe Procedure, 2014.

Bursi E, Barbieri L, Lancellotti I, Saccani A, Bignozzi M (2017) Lead waste glasses management: Chemical pretreatment for use in cementitious composites. Waste Manag Res 35(9):958-966

Chen B, Wang K, Chen X, Lu A (2012) Study of foam glass with high content of fly ash using calcium carbonate as foaming agent. Mater Lett 79:263-265

Chen Ch, Feng Kq, Zhou Y et al (2017) Effect of sintering temperature on the microstructure and properties of foamed glass-ceramics prepared from high-titanium blast furnace slag and waste glass. Int J Miner Metall Mater 24:931-936. https://doi.org/10.1007/ s12613-017-1480-8

Demirboga R (2003) Influence of mineral admixtures on thermal conductivity and compressive strength of mortar. Energy and Buildings 35(2): 189-192

El-eswed, B.I., 2020. Chemical evaluation of immobilization of wastes containing $\mathrm{Pb}, \mathrm{Cd}, \mathrm{Cu}$ and $\mathrm{Zn}$ in alkali-activated materials: A critical review. J Environ Chem Eng 104194.

El-eswed BI, Aldagag OM, Khalili FI (2017) Efficiency and mechanism of stabilization/solidification of $\mathrm{Pb}(\mathrm{II}), \mathrm{Cd}(\mathrm{II}), \mathrm{Cu}(\mathrm{II}), \mathrm{Th}(\mathrm{IV})$ and U(VI) in metakaolin based geopolymers. Appl Clay Sci 140:148-156

Elkersh, H. A.M. R., 2014. Innovative cleaner production technique: foam glass production from lead crystal glass sludge. M.SC. Thesis, School of Sciences and Engineering, the American University in Cairo, Egypt.

FC (2007), Environmental, Health, and Safety Guidelines for Glass Manufacturing, International Finance Corporation-World Bank Group report on 30 April 2007, available

Ge R, Zheng Y (2020) Measuring effective thermal conductivity of micro-particle porous materials in fixed bed by thermal probe method. Heat Mass Transf 56(9):2681-2691

Gerlach, G. and Maser, K., (2016) A self-consistent model for thermal oxidation of silicon at low oxide thickness. Advances in Condensed Matter Physics, 2016.

Hassan, H.S., Abdel-Gawwad, H.A., García, S.V. and Israde-Alcántara, I., (2018) Fabrication and characterization of thermally-insulating coconut ash-based geopolymer foam. Waste Management, 80, pp.235-240. http://www.chem.unep.ch/pops/pdf/lead/leadexp.pdf (accessed in 15 June 2013). http://www.ifc.org/wps/wcm/conne ct/384e20804885574ebc0cfe6a6515bb18/Final\%2B-\%2BGlass\% 2BManufacturing.pdf?MOD=AJPERES\&id=1323152002618 (accessed on 21 June 2013).

Kim KH, Jeon SE, Kim JK, Yang S (2003) An experimental study on thermal conductivity of concrete. Cem Concr Res 33(3):363-371

König J, Nemanič V, Žumer M, Petersen RR, Østergaard MB, Yue Y, Suvorov D (2019) Evaluation of the contributions to the effective thermal conductivity of an open-porous-type foamed glass. Constr Build Mater 214:337-343

König J, Petersen RR, Iversen N, Yue Y (2018) Suppressing the effect of cullet composition on the formation and properties of foamed glass. Ceram Int 44(10):11143-11150. https://doi.org/10.1016/j. ceramint.2018.03.130

Li J, Hashimoto Y, Riya S, Terada A, Hou H, Shibagaki Y, Hosomi M (2019) Removal and immobilization of heavy metals in contaminated soils by chlorination and thermal treatment on an industrial-scale. Chem Eng J 359:385-392

Li J, Li J, Wei H, Yang X, Benoit G, Jiao X (2021) Alkaline-thermal activated electrolytic manganese residue-based geopolymers for efficient immobilization of heavy metals. Construction and Building Materials 298:123853

Long WJ, Lin C, Ye TH, Dong B, Xing F (2021) Stabilization/solidification of hazardous lead glass by geopolymers. Construction and Building Materials 294:123574

McLellan B, Williams R, Lay J, van Riessen A, Corder G (2011) Costs and carbon emissions for geopolymer pastes in comparison to ordinary Portland cement. J Clean Prod 19:1080-1090

Nguyen, N.T., (2011) Micromixers: fundamentals, design and fabrication. 2nd edition, William Andrew, 113-161, 2012

Nikolić V, Komljenović M, Marjanović N, Baščarević Z, Petrović R (2014) Lead immobilization by geopolymers based on mechanically activated fly ash. Ceram Int 40(6):8479-8488

Niu M, Li G, Wang Y, Li Q, Han L, Song Z (2018) Comparative study of immobilization and mechanical properties of sulfoaluminate cement and ordinary Portland cement with different heavy metals. Constr Build Mater 193:332-343

Nowak B, Pessl A, Aschenbrenner P, Szentannai P, Mattenberger H, Rechberger $\mathrm{H}$ et al (2010) Heavy metal removal from municipal solid waste fly ash by chlorination and thermal treatment. J Hazard Mater 179:323-331

Nowak B, Frias Rocha S, Aschenbrenner P, Rechberger H, Winter F (2012) Heavy metal removal from MSW fly ash by means of chlorination and thermal treatment: influence of the chloride type. Chem Eng J 179:178-185

Pechnikov AV, Guseva TV, Kemp RG (1996) Environmental protection in the Russian Federation: A case study of lead contamination around a crystal production facility. Process Saf Environ Prot 74(3):189-196

Praveen Kumar TN, Venkateswaran S, Seetharamu S (2015) Effect of Grain Size of Calcium Carbonate Foaming Agent on Physical Properties of Eutectic Al-Si Alloy Closed Cell Foam. Trans Indian Inst Met 68:109-112. https://doi.org/10.1007/ s12666-015-0631-8

Rajak DK, Mahajan NN, Das S (2019) Fabrication and investigation of influence of $\mathrm{CaCO} 3$ as foaming agent on $\mathrm{Al}-\mathrm{SiCp}$ foam. Mater Manuf Processes 34(4):379-384

Saparuddin DI, Hisham NAN, Ab Aziz S, Matori KA, Honda S, Iwamoto Y, Zaid MHM (2020) Effect of sintering temperature on the crystal growth, microstructure and mechanical strength of foam glass-ceramic from waste materials. J Market Res 9(3):5640-5647

Shen Z, Hou D, Xu W et al (2018) Assessing long-term stability of cadmium and lead in a soil washing residue amended with $\mathrm{MgO}$-based binders using quantitative accelerated ageing. Sci Total Environ 643:1571-1578

Shen Z, Pan S, Hou D et al (2019) Temporal effect of MgO reactivity on the stabilization of lead contaminated soil. Environ Int 131:104990

Shen Z, Pan S, Hou D et al (2019) Temporal effect of MgO reactivity on the stabilization of lead contaminated soil. Environ Int $131: 104990$ 
Soloki A, Esmailian M (2015) Carbonate-Foaming Agents in Aluminum Foams: Advantages and Perspectives. Metall Mater Trans B 46:1052-1057. https://doi.org/10.1007/s11663-014-0262-1

Turner L, Collins F (2013) Carbon dioxide equivalent (CO2-e) emissions: a comparison between geopolymer and OPC cement concrete. Constr Build Mater 43:125-130

UNEP (2013), Lead exposure and human health, global opportunities for reducing the use of leaded gasoline, available online

USEPA, (1992) Synthetic Precipitation Leaching Procedure (SPLP), EPA Method 1312, Washington, U.S.A.

Wang X, Huang Y, Liu C, Zhang S, Wang Y, Piao G (2017) Dynamic volatilization behavior of $\mathrm{Pb}$ and $\mathrm{Cd}$ during fixed bed waste incineration: Effect of chlorine and calcium oxide. Fuel 192:1-9

Wang Y, Ni W, Zhang S, Li J, Suraneni P (2020) Optimal Mixture Designs for Heavy Metal Encapsulation in Municipal Solid Waste Incineration Fly Ash. Appl Sci 10(19):6948

Wang YS, Dai JG, Wang L, Tsang DC, Poon CS (2018) Influence of lead on stabilization/solidification by ordinary Portland cement and magnesium phosphate cement. Chemosphere 190:90-96
Xia XC, Chen XW, Zhang Z, Chen X, Zhao WM, Liao B, Hur B (2013) Effects of porosity and pore size on the compressive properties of closed-cell $\mathrm{Mg}$ alloy foam. Journal of Magnesium and Alloys 1(4):330-335

Yu J, Sun L, Xiang J, Hu S, Su S (2013) Kinetic vaporization of heavy metals during fluidized bed thermal treatment of municipal solid waste. Waste Manage 33(2):340-346

Zhan BJ, Li J-S, Xuan DX, Poon CS (2020) Recycling Hazardous Textile Effluent Sludge in Cement-Based Construction Materials: Physicochemical Interactions between Sludge and Cement. J Hazard Mater 381:121034

Zhou M, Ge X, Wang H, Chen L, Chen X (2017) Effect of the CaO content and decomposition of calcium-containing minerals on properties and microstructure of ceramic foams from fly ash. Ceram Int 43(12):9451-9457. https://doi.org/10.1016/j.ceram int.2017.04.122

Publisher's note Springer Nature remains neutral with regard to jurisdictional claims in published maps and institutional affiliations. 